\title{
The Canadian Assisted Human Reproduction Act: Protecting Women's Health While Potentially Allowing Human Somatic Cell Nuclear Transfer into Non-Human Oocytes
}

Roxanne Mykitiuk

Osgoode Hall Law School of York University, rmykitiuk@osgoode.yorku.ca

Jeff Nisker

Robyn Bluhm

Source Publication:

American Journal of Bioethics. Volume 7, Number 2 (2007), p. 71.

Follow this and additional works at: https://digitalcommons.osgoode.yorku.ca/scholarly_works

Part of the Health Law and Policy Commons

(c) (i) $\Theta \Theta$

This work is licensed under a Creative Commons Attribution-Noncommercial-No Derivative Works 4.0 License.

\section{Recommended Citation}

Mykitiuk, Roxanne, Jeff Nisker, and Robyn Bluhm. "The Canadian Assisted Human Reproduction Act: Protecting Women's Health While Potentially Allowing Human Somatic Cell Nuclear Transfer into NonHuman Oocytes." American Journal of Bioethics 7.2 (2007): 71.

This Article is brought to you for free and open access by the Faculty Scholarship at Osgoode Digital Commons. It has been accepted for inclusion in Articles \& Book Chapters by an authorized administrator of Osgoode Digital Commons. 


\section{The Canadian Assisted Human Reproduction Act: Protecting Women's Health While Potentially Allowing Human Somatic Cell Nuclear Transfer into Non-Human Oocytes}

\section{Roxanne Mykitiuk, York University Jeff Nisker, University of Western Ontario Robyn Bluhm, University of Western Ontario}

Caulfield and Bubela (2007) argue that the Canadian Assisted Human Reproduction Act (An Act Respecting Assisted Human Reproduction and Related Research (S.C. 2004, c.2) imposes a complete "criminal ban" on somatic cell nuclear transfer (SCNT) that is unwarranted because, they contend, the ban was based on concerns regarding the moral status of the human embryo, which is inappropriate in a "pluralistic society." Based on a close reading of the Act's provisions, we will suggest that the Act may not impose a complete "criminal ban" on human SCNT. We will begin, however, by briefly illustrating that the protection of the health and safety of women, rather than a concern about the moral status of the embryo, is at the center of the criminal ban on SCNT into the oocytes of women and that the ban is grounded in (what they acknowledge as) a "lengthy legislative process," rather than the parliamentary debates privileged in their article.

The Act contains seven guiding principles "that govern the Act and decisions taken under [it]" (Rivard and Hunter 2005, 35), including: the protection of health and safety of Canadians; recognition of the particular position of women in relation to reproductive technologies; concerns about the commodification of human reproductive material and processes; and concerns regarding adherence to the principle of informed consent (s.2). Enshrining these principles in the Act protects women from the harms of undergoing medically unnecessary surgical procedures to remove their oocytes for SCNT research or any reason other than their reproductive goals (Nisker 2001; Nisker and White 2005). Indeed, recent examples of the exploitation of women who undergo surgery to provide oocytes for human embryonic stem cell research, including women working in the laboratories of stem cell researchers in South Korea (Chong 2006; Nisker and White 2005; Nisker et al. 2006) as well as other socioeconomically disadvantaged women (Nisker and White 2005), are reasons why "criminal bans" like those in Canada's Act should exist in all countries where assisted reproduction is offered. Concerns about the health and safety of women and children, as Caulfield and Bubela (2007) acknowledge, have been consistently expressed throughout the "lengthy legislative process" that led to the Act.

A careful examination of the Act's provisions provides no evidence that the moral status of the embryo is of 
paramount concern. In fact, the Act does not ban research on human embryos, unlike the legislation in Italy and other countries referred to by Caulfield and Bubela (2007) where the ban is based on religious views or in Germany and other countries where non-religious perspectives inform a complete ban on all embryo research. Rather, the Act prohibits the creation of embryos for research purposes (s.5.(1)(b)), while permitting the research use of embryos donated by individuals or couples whose embryos were created for their reproductive purposes and are no longer required for that purpose (Nisker and White 2005). In addition, the Act allows embryos to be discarded or destroyed (s.10.(3)(b)). This approach to embryo research - just like concerns regarding the health and safety of women and commodification - can be traced to Canada's Royal Commission on New Reproductive Technologies (1993) and imbues succeeding expert panels, advisory committees, white papers, and legislation (Mykitiuk and Wallrap 2002).

Regarding a "criminal ban" on SCNT, we suggest that while the Act clearly prohibits the creation of human clones (s.5.(1)(a)) and chimeras (s.5.(1)(i)), the Act can be interpreted to permit human SCNT into the oocytes of nonhuman animals. A "human clone" is defined in the Act as: an embryo that, as a result of the manipulation of human reproductive material or an in vitro embryo, contains a diploid set of chromosomes obtained from a single-living or deceasedhuman being, foetus or embryo (s.3).

"Human reproductive material" is defined under the Act to mean "a sperm, ovum or other human cell or a human gene, and includes a part of any of them" (s.3). The Act also prohibits the creation of all types of chimeras, defined as:

an embryo into which a cell of any non-human life form has been introduced or b) an embryo that consists of cells of more than one embryo, foetus or human being (s.3).

Significantly, the legislators chose to include in the Act (s.3) a definition of a hybrid that is defined as:

(a) a human ovum that has been fertilized by a sperm of a nonhuman life form;

(b) an ovum of a non-human life form that has been fertilized by a human sperm;

(c) a human ovum into which the nucleus of a cell of a nonhuman life form has been introduced;

(d) an ovum of a non-human life form into which the nucleus of a human cell has been introduced; or (emphasis added)

(e) a human ovum or an ovum of a non-human life form that otherwise contains haploid sets of chromosomes from both a human being and a non-human life form.

The Act prohibits the creation of a hybrid "for the purpose of reproduction" and the transfer of a hybrid "into either a human being or a non-human life form" (s.5.(1)(j)). Therefore not all creations and uses of hybrids are prohibited. Further, using non-human oocytes as cells into which human somatic nuclear material is transferred creates a hybrid and 
not a clone.

Read together, these provisions can be interpreted to mean that while there are "criminal bans" on all creations of clones (s.5.1(a)) and chimeras (s.5.1(i)), the "criminal ban" on the creation of hybrids relates to their specific uses for reproduction or transfer, and to specific strategies of creation that are prohibited in other sections of the Act, such as by SCNT into oocytes purchased from women (s.7.(1)). One might argue that the hybrid form (hybrid d) that we contend presents the greatest opportunity for SCNT research in Canada (as discussed later in text), could also be a clone as defined in the Act due to the expanded definition of "human reproductive material" (s.3), which includes somatic cells. In this definition, materials other than "sperm" and "ovum" could include somatic cells. But, the Act must be interpreted to achieve consistency and coherence.

We suggest that because the Act legislates specifically with respect to a definition of hybrid, the definition of human clone provided in the Act is exclusive of those entities that are hybrids. Moreover, "embryo" as defined in the Act, and referred to in the definition of human clone, "means a human organism... and includes any cell derived from such an organism that is used for the purpose of creating a human being" (s.3). While the Act does not expressly make a distinction between human embryos and hybrid embryos as is the case in New Zealand's Human Assisted Reproductive Technology Act (2004), our view is that, by legislating specifically about hybrids, and permitting their creation but not permitting their use for reproduction or transfer, the Act draws a distinction between human and hybrid. Further, as a hybrid embryo, created from human SCNT into a non-human oocyte, has both human (nuclear) and non-human (mitochondrial) DNA, it is difficult to characterize it as a human embryo.

Although reservations exist regarding the feasibility of SCNT into a non-human oocyte (hybrid d), there is evidence that this approach may be useful in the report of an embryo created by human SCNT into the oocyte of a cow (Lanza et al. 1999) and that of a rabbit (Chen et al. 2003). In 2006, several groups of British scientists submitted applications to the Human Fertilisation and Embryology Authority for permission to pursue this line of research. As there are relatively few cryopreserved human embryos in Canada that can be donated to stem cell research (Baylis and Ram 2006; Nisker et al. 2006), unlike Australia and other countries where in vitro fertilization is publicly funded and large numbers of cryopreserved embryos (no longer required for reproductive purposes) are donated to research purposes (Nisker et al. 2006), SCNT research using oocytes of non-humans could allow Canadian scientists to participate in this field of investigation without harming women.

We believe that Canada's Assisted Human Reproduction Act allows for SCNT research to occur, including that related to stem cell research, while protecting the health and safety of women in relation to assisted reproductive technologies, but only in this very limited circumstance. Further, we believe this research must be carried out pursuant to other restrictions such as those in the Act pertaining to licensing (s.10.(1)) and the destruction of embryos within 14 
days (s.5.(1)(d)). We suggest open and broad discussion on the use of oocytes of non-human animals for SCNT research, and ask Health Canada to conduct public consultations to make sure Canadians want the Act to be interpreted to allow this strategy.

Address correspondence to Jeff Nisker, Schulich School of Medicine \& Dentistry, University of Western Ontario, University Hospital, Rm. A9-311,339 Windermere Rd., London, Ontario, Canada. E-mail: jeff.nisker@lhsc.on.ca

\section{REFERENCES}

Baylis, F., and N. Ram. 2006. Eligibility of cryopreserved human embryos for stem cell research in Canada the importance of empirical research in bioethics: The case of human embryo stem cell research: In response. Journal of Obstetrics and Gynaecology Canada 28(1): 15-16.

Caulfield, T., and T. Bubela. 2007. Why a criminal ban?: Analyzing the arguments against somatic cell nuclear transfer in the Canadian parliamentary debate. American Journal of Bioethics 7(2): 51-61.

Chen, Y., Z. X. He, A. Liu, K. Wang, W. W. Mao, J. X. Chu, Y. Lu, Z. F. Fang, Y. T. Shi, da Y. Chen, M. K. Wang, J. S. Li, S. L. Huang, X. Y. Kong, Y. Z. Shi, Z. Q. Wang, J. H. Xia, Z. G. Long, Z. G. Xue, W. X. Ding, and H. Z. Sheng. 2003. Embryonic stem cells generated by nuclear transfer of human somatic nuclei into rabbit oocytes. Cell Research 13(4): 251-263.

Chong, S. 2006. Investigations document still more problems for stem cell researchers. Science 311(5762): 754-755.

Cyranoski, D. 2005. Korea's stem-cell stars dogged by suspicion of ethical breach. Nature 429: 3.

Lanza, R. P., J. B. Cibelli, and M. D. West. 1999. Human therapeutic cloning. Nature Medicine 5(9): 975-977.

Mykitiuk, R., and A. Wallrap, 2002. Regulating reproductive tech- nologies in Canada. In Canadian Health Law and Policy 2 nd Edition, ed. J. Downie, T. Caulfield and C. Flood, 367-431. Toronto, ON: Butterworths.

Nisker, J. 2001. Physician obligation in oocyte procurement. Ameri- can Journal of Bioethics 1(4): 22-23.

Nisker J., A. White, F. Tekpetey, and V. Feyles. 2006. Devel- opment and investigation of a free and informed choice pro- cess for embryo donation to stem cell research in Canada. Journal of Obstetrics and Gynaecology Canada 28(8): 903-908.

Nisker J., and A White. 2005. The CMA Code of Ethics and the donation of fresh embryos for stem cell research. Canadian Medical Association Journal 173(6): 621-622.

Rivard G., and J. Hunter. 2005. Law of assisted human reproduction. Markham, ONT: Lexis Nexis Canada. 